\title{
Impact of planktonic food web structure on nutrient retention and loss from a late summer pelagic system in the coastal northern Baltic Sea
}

\author{
Anna-Stiina Heiskanen***, Timo Tamminen**, Kjell Gundersen*** \\ Tvärminne Zoological Station, University of Helsinki, FIN-10900 Hanko, Finland
}

\begin{abstract}
A large-scale mesocosm experiment was carried out in the coastal area of the northern Baltic Sea in order to study limiting (bottom-up) and controlling (top-down) factors of the late summer pelagic community. The experiment was conducted in 5 floating $30 \mathrm{~m}^{3}$ mesocosms manipulated with nutrient ( $\mathrm{N}$ and $\mathrm{P}$ ) enrichments and fish (stickleback fry) according to a cross-over experimental design with rotating treatments. Concentrations of particulate organic C, N, P, and chlorophyll $a$ as well as the development of bactena, phytoplankton, protozoa, and mesozooplankton biomass were followed for $21 \mathrm{~d}$, and sedimentation was measured. Nutrient enrichments induced phytoplankton blooms with equal biomass peak levels in all mesocosms. However, the timing of the enrichment and the effect of the top-down manipulation resulted in diversified structure of planktonic communities in each mesocosm. Basically 2 kinds of system emerged: (1) mesocosms that had received nutrients immediately after the start of the experiment developed towards more regenerating systems where both $N$ and $P$ were retained to greater extent; (2) mesocosms that received nutrients after a $5 \mathrm{~d}$ lag-period developed towards a 'new production' type of system. In the latter kind, accumulation and loss of $\mathrm{N}$ followed closely the development of autotrophic biomass. In all mesocosms, $\mathrm{N}$-limitation was maintained due to greater sedimentary loss of $N$, while $P$ was retained more effectively within the detrital pool of the pelagic system. The cascading effect of top-down manipulation influenced the grazer community and resulted in a different functional response in each manipulated mesocosm. These results indicate that during the process of eutrophication, the food web structure, timing of the fertilization, and alternative grazing/predation strategies of the planktonic heterotrophs have a crucial impact on the retention and loss of nutrients from the pelagic system.
\end{abstract}

KEY WORDS: Planktonic food web Carbon - Nitrogen Phosphorus - Sedimentation - Eutrophication 'Top-down' and 'bottom-up' manipulations · Baltic Sea

\section{INTRODUCTION}

Eutrophication in aquatic ecosystems is a result of complex interactions between nutrient enrichment and the feed-back mechanism of the planktonic food web. Algal biomass growth is controlled from 'bottom-up' through nutrient limitation and resource competition and from 'top-down' by zooplankton grazing, predation, and sedimentation. The interactions between

-E-mail: anna-stiina heiskanen@vyh.fi

Present addresses.

- Finnish Environment Institute, PO Box 140, FIN-00251 Helsinki, Finland

-.Bermuda Biological Station for Research, 17 Biological Lane, Ferry Reach GE 01, Bermuda these controlling mechanisms determine the structure and biomass level of the planktonic food web (Sommer 1988, Thingstad \& Sakshaug 1990, Mazumder et al. 1992). Retention and export of the produced biomass and assimilated nutrients depend on the food web structure, life cycle strategies, and behavior of the dominating organisms within the planktonic community (Peinert et al. 1989, Wassmann 1993, Elser et al. 1995). A large number of mesocosm experiments related to 'top-down' and 'bottom-up' control of the planktonic food web and consequently on allocation of carbon and nutrients in the pelagic system have been conducted in freshwater environments (e.g. Carpenter et al. 1985, McQueen et al. 1986, Threlkeld 1988, Bloesch \& Burgi 1989, Mazumder et al. 1992), while 
studies combining both approaches have been less common in marine and estuarine investigations (see for example Horstedt et al. 1988, Riemann et al. 1988 , Granéli et al. 1993)

Several studies conducted mainly in freshwater environments have demonstrated that nutrient enrichments combined with high zooplankton grazing pressure lead to dominance of larger grazing-resistant cells (e.g. Lynch \& Shapiro 1981, Hessen et al. 1986, Horstedt et al. 1988, Mazumder et al. 1988). Consequently, sedimentary losses of particulate nutrients tend to increase due to the higher sinking velocities of larger cells (Bloesch \& Burgi 1989, Mazumder et al. 1989) and increased contribution of zooplankton fecal material to the settling flux (Bloesch \& Burgi 1989). Addition of visually feeding planktivorous fish reduces the numbers of larger herbivores, and leads to a biomass increase of nanoplankton, generally favored by zooplankton grazers (Hessen et al. 1986, Mazumder et al. 1988, Drenner et al. 1989), as well as to a subsequent decline of sedimentation rates and retention of nutrients in the pelagic system (Mazumder et al. 1992). However, some recent observations and model predictions indicate that the effect of zooplankton on the retention or loss of nutrients may be controversial depending on the feeding and reproduction strategies of the dominant species both in marine and freshwater environments (Peinert et al. 1989, Aksnes \& Wassmann 1993. Wassmann 1993). Also the site-dependent factors related to the morphological and physical characteristics of the basin may be crucial (Elser et al. 1995). Furthermore, zooplankton regulate phytoplankton species composition and interspecific competition not only through grazing but also by assimilating a relatively constant proportion of $\mathrm{P}$ and $\mathrm{N}$ from food components and by decreased excretion of the element in demand (Elser et al. 1988, Sterner 1989, Andersen \& Hessen 1991) Thus, the species composition and structure of the pelagic food web may shift the initial elemental ratio of the nutrient supply to a direction that may be limiting for a given element assimilated by the higher levels of the food web

The concept of 'top-down' and 'bottom-up' control is further complicated by the trophic interactions and nutrient fluxes within the microbial loop (Azam et al. 1983). The cascading effects of fish predation and zooplankton grazing are not only channeled through the grazing food chain on nano- and microphytoplankton, but the alternative feeding strategies of crustacean zooplankton on protozoa and algae (Stoecker \& Capuzzo 1990, Kleppel 1993) affect the biotic interactions within the microbial loop by suppressing the protozoan microzooplankton and further influencing the protozoa-bacteria interactions (Kivi et al. 1993). Allocation of rutrient enrichment either to picoplanktonic algae (and further to the microbial loop) or to the larger nano-or microplanktonic algae will also have a crucial impact on the fate of the produced biomass (Thingstad \& Sakshaug 1990, Wehr \& Campbell 1994). However, the perturbations caused by nutrient enrichments and top-down manipulations were observed to affect the microbial loop only moderately, while the major impact was channeled to larger (nano-) planktonic algae (Kuuppo-Leinikki et al. 1994)

Coastal waters of the northern Baltic Sea provide a brackish water environment which comprises characteristics from both the limnic and marine systems. Salinity in the study area, at the entrance of the Gulf of Finland, is rather low ( 5 to 7 psu) and only a few species of plants and animals tolerate it. However, the plankton community comprises species of marine, brackish, and freshwater origin, although both large freshwater daphnids and large marine copepods are absent in the zooplankton community (Niemi 1975, Kivi 1986, Viitasalo 1992). The seasonal succession of the planktonic community is typical for northern boreal regions, with high phytoplankton biomass during the vernal new production period followed by low standing stock and primary production and increasing dominance of heterotrophic biomass during the regenerated production period in summer (Kivi 1986, Kuosa \& Kivi 1988, Lignell 1990, Heiskanen \& Kononen 1994). However, considerable short-term fluctuations of water column salinity, temperature, and available nutrients are caused by horizontal advection of water masses as well as by frequent upwelling of deep water into the study area (Haapala 1994). A detailed description of the study area is presented by Niemi (1975).

The effect of nutrient enrichments on the function and structure of the planktonic community has been studied experimentally at the study site since the early 1980s (Tamminen et al. 1985). These mesocosm experiments combined with top-down manipulations either by predator addition (Uitto et al. 1995) or by removal of large crustaceans by prefractionation (Kivi et al. 1993) have demonstrated that in summer continuous nutrient limitation was coupled to strict grazing/predation control of the planktonic community (Kivi et al. 1993). The present experiment was designed to assess the effects of single and combined nutrient enrichments and the presence or absence of a top predator (fish) on the structure and functioning of a late summer planktonic community. Cross-over experimental design with rotating treatments (Table 1) was applied in order to study the direct, carry-over, and cumulative effects of the manipulations. The effect of manipulations on microbial loop dynamics (bacterial biomass and production, picoplankton, heterotrophic flagellates and ciliates) has already been presented by KuuppoLeinikki (1990) and Kuuppo-Leinikki et al. (1994). 
Mesozooplankton grazing dynamics during the experiment were studied by Uitto (in press), and the biochemical algal ${ }^{14} \mathrm{C}$-fractions by Lignell \& Lindquist (1992). In the present paper we describe the effect of manipulations on accumulation and loss of nutrients in relation to the planktonic community structure and biomass distribution in the experimental enclosures.

\section{MATERIAL AND METHODS}

The experiment was conducted during late summer (23 July to 12 August 1988, total duration of $21 \mathrm{~d}$ ) in the archipelago region of the southwest coast of Finland, in the close vicinity of the Trärminne Zoological Station. At the beginning of the experiment, the salinity of surface water was 6 psu and temperature $21.5^{\circ} \mathrm{C}$. There was a drastic decline of temperature from 18 to $11^{\circ} \mathrm{C}$ between 29 and 31 July due to upwelling in the study area (Kuuppo-Leinikki 1990. Haapala 1994).

Five floating plastic mesocosms (units), with a volume of ca $30 \mathrm{~m}^{3}$ each (depth $9 \mathrm{~m}$, diam. $2.15 \mathrm{~m}$ ), were filled with ambient seawater containing the natural planktonic community by lifting them from $15 \mathrm{~m}$ depth to the surface (maximum depth at the location ca $26 \mathrm{~m}$ ). Enclosures were manipulated by daily nutrient additions (16 $\mu \mathrm{g} \mathrm{NH}_{4}-\mathrm{N} \mathrm{I}^{-1}$ and $4 \mu \mathrm{PO}_{4}-\mathrm{Pl}^{-1}$ ) and by the presence or absence of planktivorous fish fry (stickleback fry Gasterosteus aculeatus L.) according to cross-over experimental design, which implies rotating manipulations of the experimental mesocosms (Table 1). Nutrient enrichments were started on Day 2, and the additions were made each day after water column sampling. Stickleback fry (90 specimens per unit) were added into Units 3 and 4 during the first experimental day and removed on Day 11 (recovery of sticklebacks was ca 90\%). In the evening of Day 11 new sticklebacks were introduced into Units 1 and 2 (Table 1). Samples for particulate nutrients and chlorophyll a ( $\mathrm{chl} \mathrm{a)} \mathrm{were} \mathrm{taken} \mathrm{each} \mathrm{morning} \mathrm{at} 1 \mathrm{~m}$ intervals between 0 and $5 \mathrm{~m}$ depth and pooled. Inorganic nutrients were analyzed in samples taken from 0

Table 1 Manipulations in the cross-over experiment. $(\mathrm{P}+\mathrm{N}$ : nutrient addition; Fish: stickleback fry; +: manipulation present -: no manipulation)

\begin{tabular}{|c|c|c|c|c|c|c|c|c|}
\hline \multirow[t]{3}{*}{ Unit } & \multicolumn{8}{|c|}{ Period } \\
\hline & Days & $2-6$ & Days & $7-11$ & Days 1 & $2-16$ & Days 1 & $7-21$ \\
\hline & $P+N$ & Fish & $P+N$ & Fish & $P+N$ & Fish & $\mathrm{P}+\mathrm{N}$ & Fish \\
\hline 1 & - & - & + & - & - & + & + & + \\
\hline 2 & + & - & - & - & + & + & - & + \\
\hline 3 & - & + & + & + & - & - & + & - \\
\hline 4 & + & + & - & + & + & - & - & - \\
\hline 5 & - & - & - & - & - & - & - & - \\
\hline
\end{tabular}

and $5 \mathrm{~m}$ depths, and integrated for average values between 0 and $5 \mathrm{~m}$ (trapezoid integration). More detailed descriptions of the enclosure construction, manipulation techniques, and sampling for other parameters are presented by Kuuppo-Leinikki et al. (1994).

Sedimentation inside the enclosures was measured with cylindrical sediment traps (diam. $10 \mathrm{~cm}$ and height $50 \mathrm{~cm}$ ) until Day 16 of the experiment, when technical problems with sediment traps emerged. Sediment traps were positioned in the middle of each enclosure at $7 \mathrm{~m}$ depth (mean depth of $1 \%$ light leve] was $7.2 \mathrm{~m}$ in Unit 5) and lifted up every morning before water column sampling Settled material from the cylinder was suspended in 2.51 of seawater and filtered for particulate nutrient analysis.

Chl a was determined fluorometrically (SequoiaTurner 450, calibrated with pure chl a, Sigma) after sonication and ethanol extraction (24 h at room temperature) from samples filtered onto glass-fiber filters (Whatman GF/F). Phosphate and ammonium were measured manually in duplicate (Grasshoff et al. 1983). Samples for particulate organic carbon (POC), particulate organic nitrogen (PON) and particulate phosphorus (PP) were filtered onto glass-fiber filters (single samples from the water column, duplicates from sediment trap samples). All glassware and glassfiber filters (Whatman GF/F) used for nutrient analyses were acid-washed and precombusted $\left(4 \mathrm{~h}\right.$ at $500^{\circ} \mathrm{C}$ ). Filters for POC and PON analyses were dried at room temperature, sealed in petri dishes and analyzed with a Heraeus CHN-O-RAPID elemental analyzer. Samples for dissolved total nitrogen (DTN) and phosphorus (DTP) were filtered through glass-fiber filters in the end of each manipulation period and stored frozen until analyzed. PP and DTP were analyzed according to Solorzano \& Sharp (1980). DTN was determined after oxidation as in total $N$ analysis (Grasshoff et al. 1983). Dissolved organic nitrogen (DON) is the value of DTN after subtraction of $\mathrm{NH}_{4}-\mathrm{N}$, thus including both $\mathrm{NO}_{3}-\mathrm{N}$ and $\mathrm{NO}_{2}-\mathrm{N}$. However, the proportion of those is only minor in comparison to the DON fraction and $\mathrm{NH}_{4}-\mathrm{N}$ during summer in the northern Baltic. Correspondingly, dissolved organic phosphorus (DOP) denotes DTP after subtraction of $\mathrm{PO}_{4}$-P.

Samples for enumeration of planktonic organisms were taken from Day 1 onwards at 2 to $3 \mathrm{~d}$ intervals. Preservation, microscopical enumeration and carbon conversion of bacteria, picoplanktonic eucaryotes and cyanobacteria, phytoplankton, autotrophic and heterotrophic nanoflagellates, and ciliates during the experiment are described by Kuuppo-Leinikki et al. (1994). Mesozooplankton samples were preserved with $4 \%$ buffered formaldehyde, and enumerated with an inverted microscope (Uitto in press). Detrital carbon was calculated by subtracting the carbon biomass of the 
sum of the planktonic organisms from the total measured POC. Before the numerical analysis, the biomass values of planktonic organisms were estimated by linear interpolation for the days when no biomass samples were taken.

Prior to statistical analyses, the normal distribution of the variables was checked by Shapiro-Wilks' test ( $W>$ $0.9 . p>0.05$ ). In most cases the null hypothesis of equal variances could be accepted (Levene test, $p>0.05$ ). In only a few cases, a minor heteroscedasticy (Levene test, $\mathrm{p}>0.01$ ) had to be approved.

\section{RESULTS}

\section{Particulate nutrients and $\mathrm{chl} a$}

The manipulated mesocosms received nutrient additions for two $5 \mathrm{~d}$ periods in an alternating, pairwise manner (i.e. Units 1 and 3, Units 2 and 4 ; see Table 1). Sharp and simultaneous chl a peaks emerged in Units 1 and 3 , while there was a phase difference of $5 \mathrm{~d}$ between the top of the bloom peaks in Units 2 and 4 (Fig. 1A). The first biomass peaks of chl a were quite

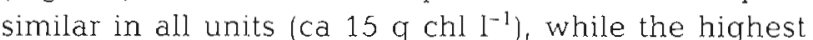
concentrations of chl in Unit 1 was observed during the last manipulation period (Fig 1A). Control Unit 5 showed consistently low concentrations of chl, which did not deviate from the levels prevailing outside the experimental mesocosms (Fig. 1A).

The most notable difference between chl $a$ and particulate nutrients was the accumulation of $\mathrm{POC}, \mathrm{PON}$ and PP. The decline of POC and PON concentrations in Units 1 and 3 after the first enrichment period (Fig. 1B, C) was not as pronounced as for chl $a$, and almost nonexistent for PP (Fig. 1D). The highest POC (1.2 mg

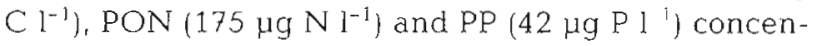
trations were reached in Unit 4 during the last enrichment period (Fig. 1B-D). The concentrations of particulate nutrients correlated significantly with chl a in all manipulated units. The lowest correlations were obtained between chl $a, P O N$, and PP in Unit 4 ( $r=0.5$, $p<0.05)$. Low concentrations of particulate nutrients prevailed in Unit 5 (Fig. 1B-D).

In Units 1 and 3 , the C:chl a ratio was lowest $(<50)$ during the bloom peak and the change was identical in both units. In Units 2 and 4, the development of the C:chl a ratio followed opposite trends, being low during the first part of the experiment in Unit 2 and during the latter part of the experiment in Unit 4 (Fig. 2A). The C:N ratio decreased significantly in Units 1 and 3 , while in Units 2 and 4 no trend was observed (Fig. 2B, Table 2). The C: $\mathrm{P}$ ratios decreased significantly in all manipulated enclosures (Table 2 ) and reached values below the Redfield ratio ( $\mathrm{C}: \mathrm{P}=41$ by weight) soon after the beginning of the experiment (Fig. 2C). Manipulated units had lower $\mathrm{C}: \mathrm{N}$ and $\mathrm{C}: \mathrm{P}$ ratios than the control (1-way ANOVA, Dunnet's a priori test, $\mathrm{p}<0.01, \mathrm{n}=$ 21). Also N:P ratios of particulate material decreased significantly in all units (Fig. 2D, Table 2). However, there was no difference between the $N: P$ ratios of manipulated and control units (1-way ANOVA, Dunnet's a priori test, $p>0.05, n=21$ ), indicating that the $\mathrm{N}$ :P ratio was relatively stable regardless of manipulations performed.

\section{Biomass and species composition of plankton}

The biomass of autotrophic algae followed the chl a concentrations in the enclosures (Fig. 3). In Units 1 and 3 , the biomass peaks on Day 12 (203 and $174 \mu \mathrm{g} \mathrm{C}^{-1}$, respectively) were mainly formed by an autotrophic nanoflagellate, Pseudopedinella sp. (Chrysophyceae; ca $60 \%$ of total phytoplankton biomass). In Units 2 and 4, the peak phytoplankton biomass was dominated by a small centric diatom. Thalassiosira pseudonana Hasle \& Heimdal (ca $40 \%$ of the total phytoplankton biomass).

Total heterotrophic biomass was initially dominated by bacteria, while the other groups (mainly micro-and mesozooplankton) increased their share towards the end of the experiment (Fig 3). In Units 2 and 3, the biomass of heterotrophic ciliates (dominated by Lohmaniella spiralis) increased during the latter part of the experiment (Fig 3). The biomass of heterotrophic nanoflagellates increased slightly in all units between Days 9 and 13, being highest in Unit 4, but decreasing soon thereafter (Fig. 3). Mesozooplankton biomass was mainly dominated by copepods (Eurytemora spp. copepodites and adults) in all units, while during the last manipulation period Synchaeta sp. (Rotatoria) formed over $80 \%$ of the total mesozooplankton biomass in Unit 4. The proportion of detrital carbon was estimated to be predominant in all units, forming ca 50 to $60 \%$ of the total organic carbon in the beginning of the experiment, and increasing up to $67 \%$ during the third manipulation period in Unit 4 (Fig. 3).

Table 2. Linear regressions between nutrent ratios and time in the different enclosures. b: slope, $\mathrm{r}^{2}$ : coefficient of determination (ns: not significant: $\mathrm{p}>0.05 ; \mathrm{n}: 21$, except Unit $1: \mathrm{n}=19$ )

\begin{tabular}{|llrcrcc|}
\hline & & Unit 1 & Unit 2 & Unit 3 & Unit 4 & Unit. 5 \\
\hline $\mathrm{C}: \mathrm{N}$ & $\mathrm{b}$ & -0.13 & $\mathrm{~ns}$ & -0.14 & $\mathrm{~ns}$ & 0.12 \\
& $\mathrm{r}^{2}$ & 0.48 & $\mathrm{~ns}$ & 0.53 & $\mathrm{~ns}$ & 0.20 \\
$\mathrm{C}: \mathrm{P}$ & $\mathrm{b}$ & -1.25 & -0.68 & -0.89 & -0.46 & 0.84 \\
& $\mathrm{r}^{2}$ & 0.79 & 0.61 & 0.55 & 0.33 & 0.45 \\
$\mathrm{~N}: \mathrm{P}$ & $\mathrm{b}$ & -0.09 & -0.08 & -0.04 & -006 & $\mathrm{~ns}$ \\
& $\mathrm{r}^{2}$ & 0.38 & 0.57 & 0.20 & 0.24 & $\mathrm{~ns}$ \\
& & & & & & \\
\hline
\end{tabular}



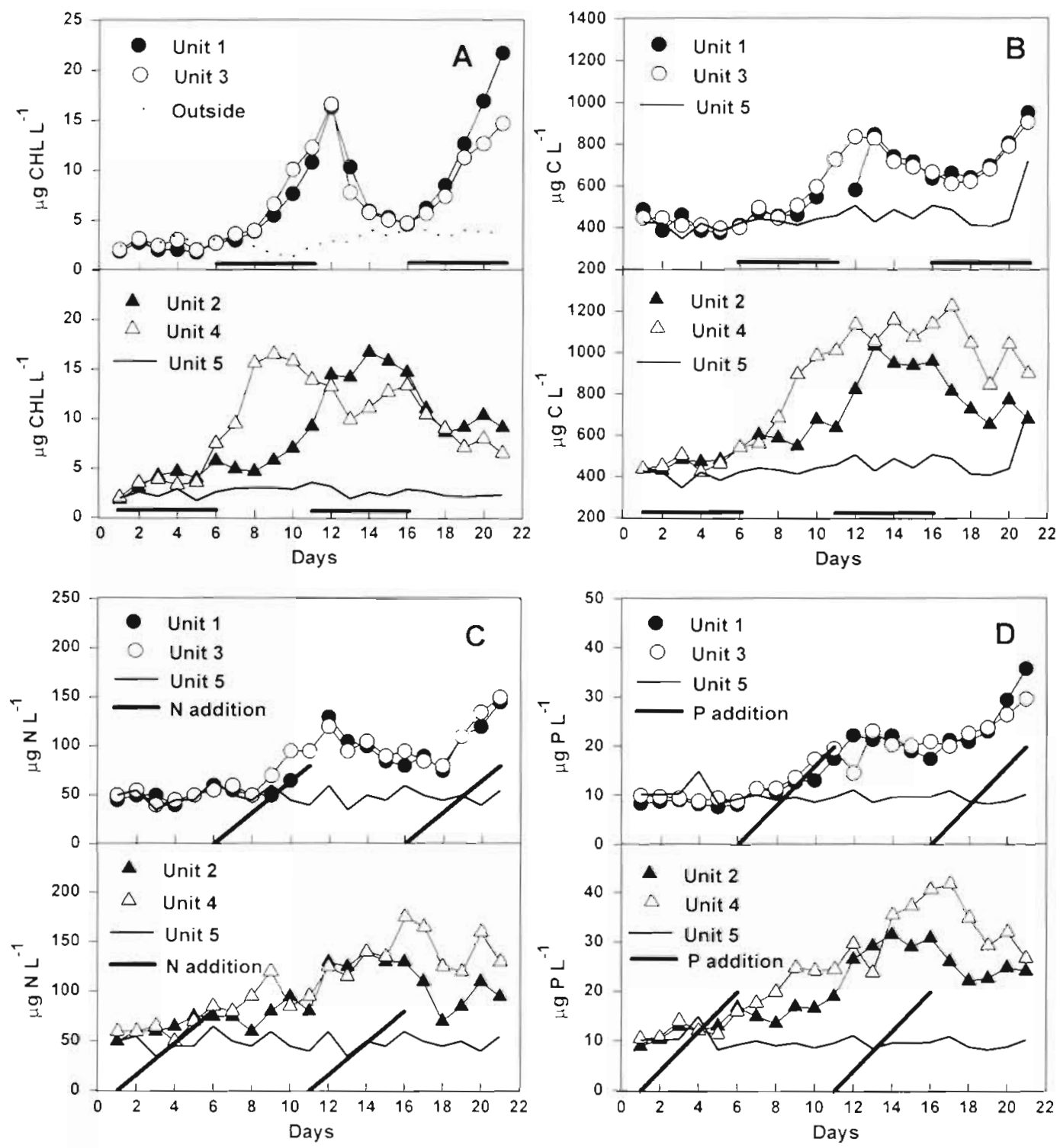

Fig. 1. (A) Concentration of chlorophyll $a$ in Units 1 and 3 and outside the experimental enclosures (upper panel), and in Units 2 and 4, and in control Unit 5 (lower panel) from Day 1 to Day 21. (B) Concentrations of particulate organic carbon in Unuts 1, 3, and 5 (upper panel), and in Units 2, 4 and 5 (lower panel). Horizontal bar denotes periods when nutrients were added to Units 1 and 3 or to Units 2 and 4 . Concentrations of (C) particulate organic nitrogen and (D) particulate phosphorus in Units 1, 3 and 5 (upper panel), and in Units 2, 4 and 5 (lower panel). Thick lines denote cumulative addition of $N$ in (C) and P in (D) to Units 1 and 3 or 2 and 4 during nutrient enrichments

\section{Nutrient fractions}

The cumulative nitrogen additions $\left(80 \mu \mathrm{g} \mathrm{NH}_{4}-\mathrm{N} \mathrm{I}^{-1}\right.$ per 5 d period) were generally recovered in Units 2 and 4 after the enrichment periods, while in Units 1 and 3 nitrogen additions were hardly detectable after the first enrichment period in the sum of measured nitrogen fractions ( $\mathrm{NH}_{4}-\mathrm{N}, \mathrm{DON}$, and PON) (Fig 4A). After the second enrichment period, nitrogen had accumulated in PON and ammonium pools in Unit 1, while in Unit 3 only the PON fraction had increased. However, the to- tal increment in both units (47 and $16 \mu \mathrm{g} \mathrm{N} \mathrm{N}^{-1}$, respectively) did not balance nitrogen additions, indicating loss of nitrogen from the pelagic system. During the latter half of the experiment, practically no measurable amounts of ammonium could be detected in the surface layer, indicating efficient utilization of the daily nutrient additions. The few exceptions (Fig. 4A) were all due to elevated ammonium concentrations in the lowest part of the euphotic zone $(5 \mathrm{~m}$ ) (data not shown). During the last $5 \mathrm{~d}$ period, decreased PON concentrations in Units 2 and 4 indicated increased sedimentation. How- 

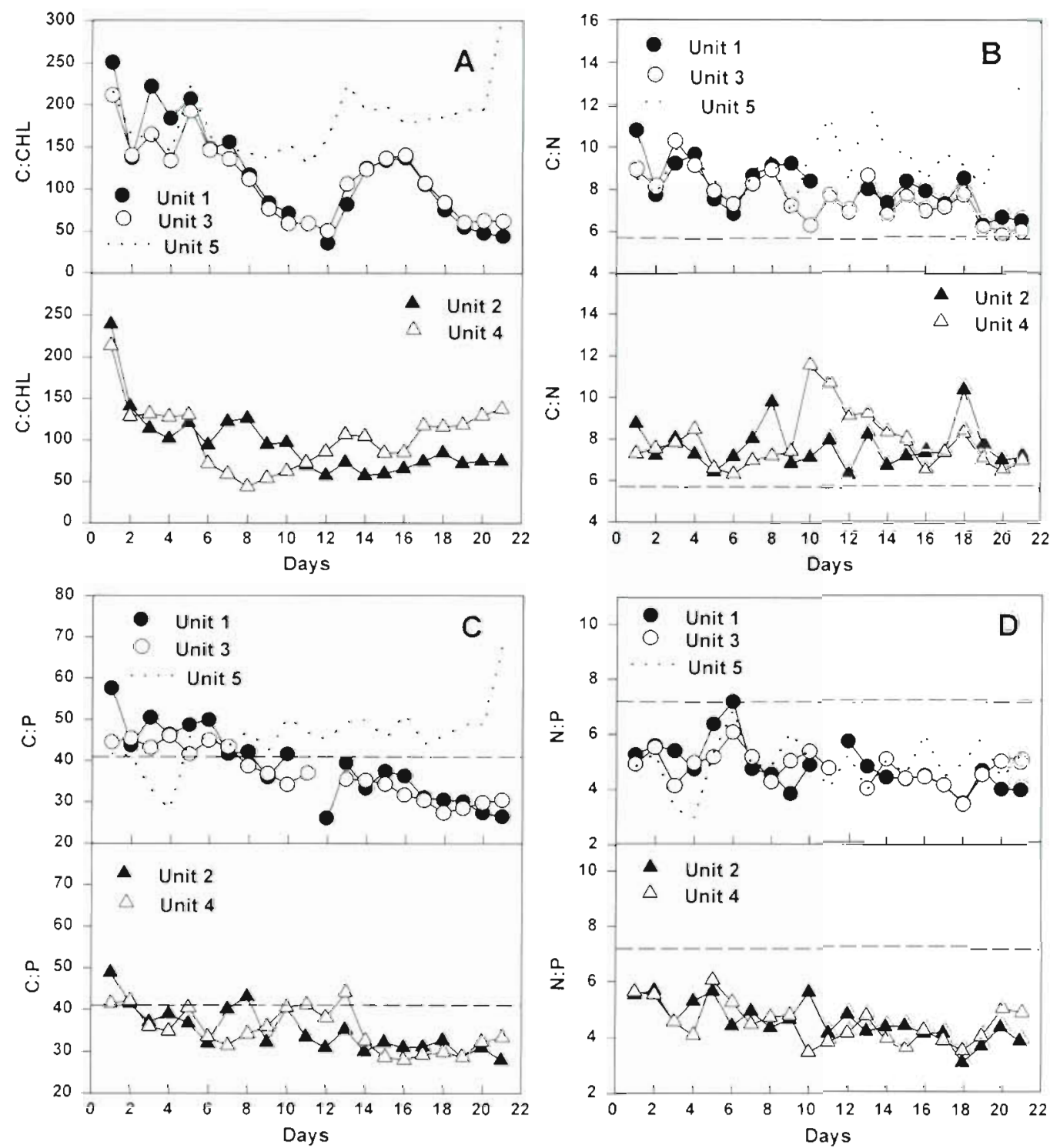

Fig. 2. (A) Carbon to chl a (C:Chl a) ratios of suspended particulate material in Unit 1 and 3 , and control Unit 5 (Upper panel) and in Units 2 and 4 (lower panel) from Day 1 to Day 21. (B) Carbon to nitrogen ratios (C:N, by weight) of suspended particulate materal in Units 1, 3, and 5 (upper panel), and in Units 2 and 4 (lower panel). Redfield's $\mathrm{C}: \mathrm{N}$ ratio (5.7 by weight) is denoted by the dashed line. (C) Carbon to phosphorus (C:P, by weight) ratios of suspended particulate material in Units 1, 3, and 5 (upper panel) and in Units 2 and 4 (lower panel). Redfield's C:P ratio (41 by weight) is denoted by the dashed line. (D) Nitrogen to phosphorus ( $N$ :P, by weight) ratios of suspended particulate material in Units 1., 3, and 5 (upper panel), and in Units 2 and 4 (lower panel). Redfield's N:P ratio (7.2 by weight) is denoted by the dashed line

ever, the total decrease (43 and $59 \mu \mathrm{g} \mathrm{N} \mathrm{l}^{-1}$, respec. tively) was lower than the previous addition $(80 \mu \mathrm{g} \mathrm{N}$ $\left.1^{-1}\right)$ also indicating accumulation of nitrogen (Fig. 4A)

A high recovery of cumulative phosphate additions (20 $\mu \mathrm{g} \mathrm{P}^{-1}$ per $5 \mathrm{~d}$ period) was generally obtained in the sum of phosphorus fractions after each enrichment period (Fig. 4B). In Units 2 and 4, PP concentrations continued to accumulate throughout the first three $5 \mathrm{~d}$ periods, and in Units 1 and 3, PP accumulated during the last three $5 \mathrm{~d}$ periods corresponding with the enrichment periods for each unit. Losses between enrichment periods were low except during the last $5 \mathrm{~d}$ period, when decreased total phosphorus concentrations indicated sedimentation in Units 2 and 4 (total decrease 17 and $23 \mu \mathrm{g} \mathrm{P} \mathrm{l^{-1 }}$, respectively). Also the

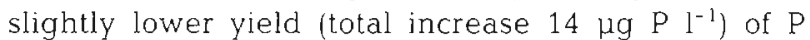
enrichment in Unit 3 was presumably due to sedimentation of PP during the last $5 \mathrm{~d}$ period (Fig. 4B). Besides the first nutrient enrichment period in each unit, inorganic phosphorus was continuously available $(>2 \mu g$ 

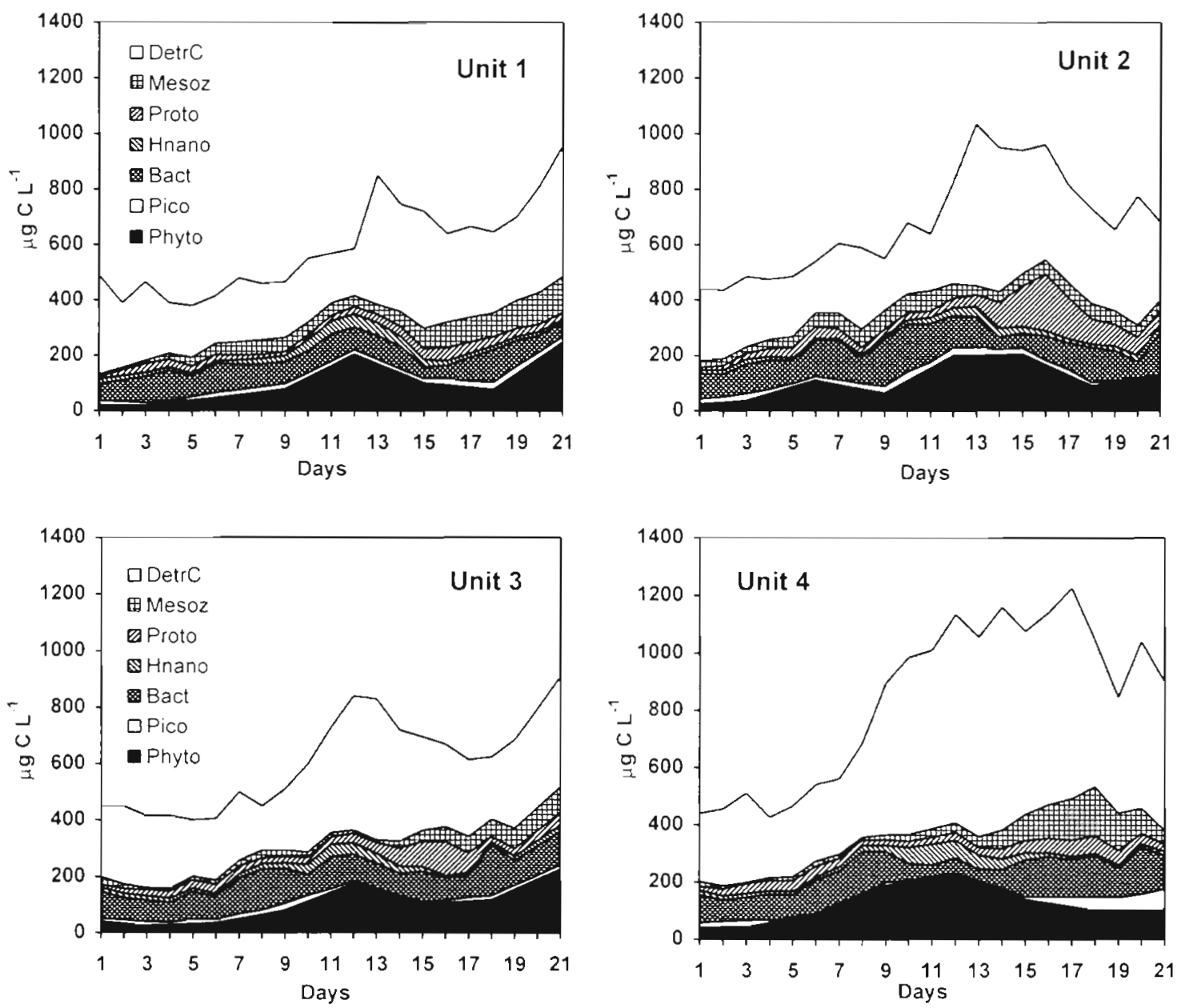

Fig. 3. Biomass fractions of particulate organic carbon (DetrC: detrital carbon; Mesoz: mesozooplankton; Proto: ciliates and other heterotrophic microprotozoa; Hnano: heterotrophic nanoflagellates; Bact: bacterial; and Pico: autotrophic picoplankton; Phyto:

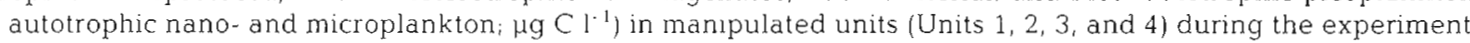

$\mathrm{PO}_{4}-\mathrm{P}^{-1}$ ) in the whole water column (data not shown) Also DOP accumulated in Unit 2 during the third and fourth manipulation period (Fig. 4B).

\section{Nutrients in settled material}

Quantitative sedimentation rates of particulate material were irregular and showed no consistent variation in relation to different manipulations (data not shown). This was probably due to the elastic construction of the enclosures, which allowed them to move continuously and change shape, driven by currents in the area. Therefore the measured sedimentation rates could not be related to any constant volume above the cylinders. Thus only the nutrient ratios of the settled material are presented.

The major source of variation in the $C: N$ ratios of settled material was generally due to sampling (daily variation: 1 -way ANOVA, $\mathrm{p}<0.05$ ) rather than due to different treatments (between enclosures: 1-way ANOVA, $p>0.05)$. C: $N$ ratios of suspended and settled material were similar in all units (paired t-test, $p>0.1$, $n=15$ ). Neither was there significant difference between the mean $C: N$ ratios of suspended and settled particulate material during the different manipulation periods when the data from all units was combined (2-sample $t$-test, $\mathrm{p}>0.05$, and $\mathrm{n}=25$; Table 3 ).

The C:P ratios of settled material had declined during the second and third periods in the manipulated units (Table 3). The settled material from the control unit had slightly higher $C: P$ ratios than in the manipulated units ( 1 -way ANOVA, $\mathrm{p}<0.05, \mathrm{n}=14$ ), but only the difference between Unit 4 and the control was significant (Tukey's a posteriori test, $\mathrm{p}=0.05$ ). However, the $C$ : $P$ ratios of suspended and settled material were significantly different in all units regardless of the manipulations (paired $t$-test, $\mathrm{p}<0.0001, \mathrm{n}=15$; Table 3 ). This suggested that although nutrient enrichments resulted in sinking loss of $\mathrm{P}$ and consequently in lower 


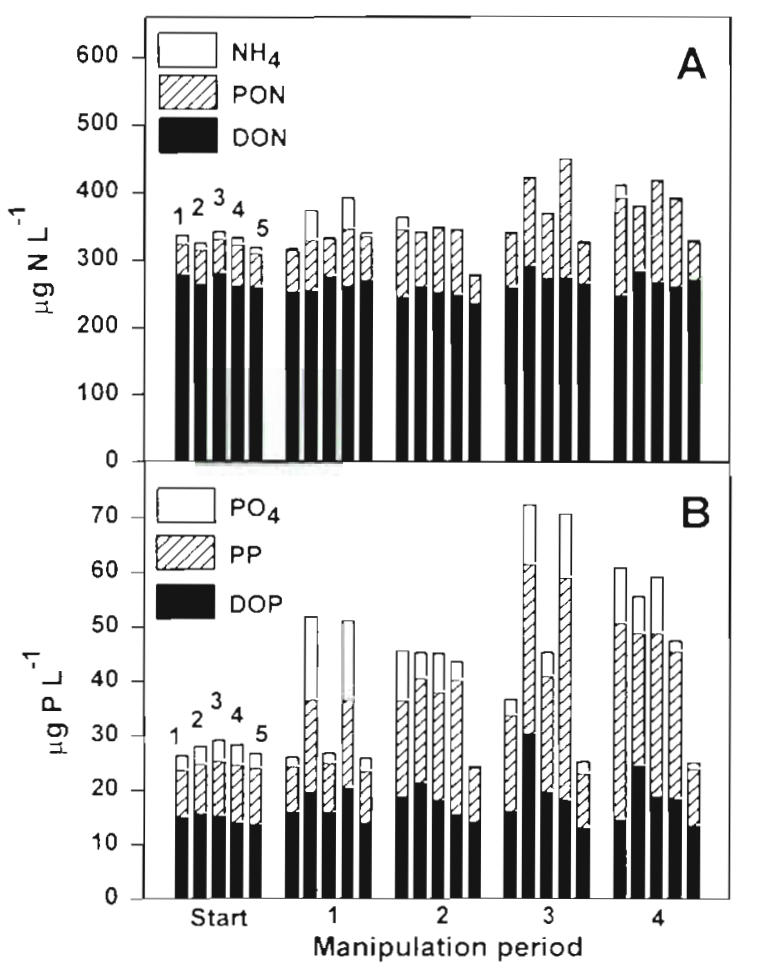

Fig. 4. (A) Fractions of total suspended nitrogen $\left(\mathrm{NH}_{4}\right.$ : ammonjum; PON: particulate organic nitrogen; DON dissolved organic nitrogen $+\mathrm{NO}_{3}$ and $\mathrm{NO}_{2} ; \mu \mathrm{g} \mathrm{N}^{-1}$ ), and (B) fractions of total suspended phosphorus ( $\mathrm{PO}_{4}$ : phosphate; PP: particu-

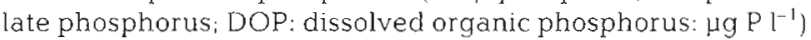
in the start of experiment (Day 1) and at the end of each manipulation period. Numbers above the first group of columns refer to the experimental units and are the same for each manipulation period

C:P ratios of settled material in manipulated units, accumulation of $\mathrm{P}$ in the suspended material occurred.

The N:P ratios of settled material were similar in all units (1-way ANOVA, $p>0.05$ ), but the settled material had significantly higher $N: P$ ratios than the suspended material regardless of the manipulation (paired $t$-test, $\mathrm{p}<0.0001, \mathrm{n}=15$ ). The average $\mathrm{N}: \mathrm{P}$ ratio of settled material had declined slightly in the manipulated enclosures during the second and third periads being consistently lower that the mean suspended $\mathrm{N}$ :P ratio which also decreased slightly (Table 3).

\section{DISCUSSION}

\section{Development of pelagic communities in the manipulated enclosures}

The initial phytoplankton biomass was low, as is typical for the regenerating summer period at the study area (Lignell 1990, Heiskanen \& Kononen 1994). The phytoplankton community was dominated
Table 3. Average nutrient ratios of suspended (SUS) and settled (SET) material \pm standard deviation in all units $(n=25)$ during the first, second and third enrichment periods (values in parentheses are the coefficients of variation percentage). "Values of suspended and settled material that are significantly different from each other ( 2 -sample $t$-test, $\mathrm{p}<0.001, \mathrm{n}=25$ )

\begin{tabular}{|ccccc|}
\hline \multicolumn{2}{l}{ Period } & \multicolumn{1}{c}{ C:N } & C:P & N:P \\
\hline 1 & SUS & $8.2 \pm 1.2$ & $42.1 \pm 6.3$ & $5.2 \pm 0.9$ \\
& & $(14.7)$ & $(15.0)^{\circ}$ & $(17.4)^{\circ}$ \\
& SET & $8.3 \pm 0.9$ & $59.3 \pm 7.5$ & $7.2 \pm 0.9$ \\
& & $(10.7)$ & $(12.7)^{\circ}$ & $(13.6)^{\circ}$ \\
2 & SUS & $8.5 \pm 1.5$ & $39.8 \pm 4.9$ & $4.7 \pm 0.6$ \\
& & $(17.1)$ & $(12.4)^{\circ}$ & $(12.5)^{\circ}$ \\
& SET & $8.2 \pm 1.1$ & $55.3 \pm 6.4$ & $6.8 \pm 0.7$ \\
& & $(13.0)$ & $(11.5)^{\circ}$ & $(10.7)^{\circ}$ \\
3 & SUS & $8.1 \pm 1.3$ & $37.6 \pm 8.2$ & $4.6 \pm 0.6$ \\
& & $(16.1)$ & $(21.9)^{\circ}$ & $(12.4)^{\circ}$ \\
& SET & $7.6 \pm 0.8$ & $47.3 \pm 9.7$ & $6.2 \pm 1.1$ \\
& & $(10.0)$ & $(20.6)^{\circ}$ & $(17.0)^{\circ}$ \\
\hline
\end{tabular}

by cyanobacteria Aphanizomenon flos-aquae (Lignell \& Lindqvist 1992) while also others, mainly freshwater algae (i.e. Cyclotella spp., Closterium acutus, Coelastrum spp.; Kuuppo-Leinikki et al. 1994), were abundant. However, these species were not able to gain advantage from nutrient enrichments, but declined or maintained constant biomass after start of the experiment. The freshwater characteristics of the species composition and the high bacterial biomass indicated that there had been a freshwater outflow from the inner parts of the archipelago to the study area prior the start of the experiment (Kuuppo-Leinikki et al. 1994)

Nutrient enrichments in manipulated enclosures led to biomass levels which corresponded to the vernal bloom biomass in the study area (Heiskanen \& Kononen 1994). However, timing of the nutrient enrichment after enclosing the phytoplankton community into the mesocosms was crucial for the later development of the community. The onset of the phytoplankton bloom initiation, biomass and community structure were almost identical in the units which received nutrients at the same time. This indicated that the interplay of nutrient deficiency and decrease of turbulence after enclosing the community into the mesocosms resulted in exclusion of diatoms in Units 1 and 3 , and favored the Chrysophycean flagellate Pseudopedinella sp. which was capable of producing a bloom when the nutrient enrichments finally commenced. Immediate nutrient additions favored the growth of a small centric diatom Thalassiosira pseudonana which could counteract losses due to sedimentation and grazing and establish a bloom in Units 2 and 4 
Although the biomass of autotrophic picoplankton increased slightly in all units, the major biomass growth due to nutrient enrichments was channeled to nanoalgae, while autotrophic picoplankton were mainly controlled by grazing of heterotrophic nanoflagellates (Kuosa 1991, Kuuppo-Leinikki et al. 1994). In a regenerating system the major source of nutrients for picoplankton is through recycling by nano- and microprotozoa which would enable maximum growth rate of picoplankton even in oligotrophic situations. Thus, the pulsed nutrient input is primarily channeled to growth of larger phytoplankton while small picoplanktonic algae are unable to scavenge nutrient enrichments (Thingstad \& Sakshaug 1990).

After the first two $5 \mathrm{~d}$ periods, bacterial biomass declined in all units coinciding with the decreasing temperature (from 17 to $10^{\circ} \mathrm{C}$ ) and with the increasing numbers of heterotrophic nanoflagellates. Temperature change influenced the activity of the microbial community through decrease in bacterial productivity and protozoan grazing efficiency. However, adaptation to lower temperature occurred within a few days (Kuuppo-Leinikki 1990). In fact, the change in temperature was interlinked with the coupled oscillation of bacterial production, biomass of heterotrophic nanoflagellates and ciliated protozoa (Kuuppo-Leinikki et al. 1994). This indicated that, although temperature drop may have had an effect on the production and grazing rates, the growth of these groups was tightly coupled and their biomass increase was mainly controlled by food web interactions of the microbial loop (i.e. grazing and predation). Still, it is likely that the ciliates obtained a considerable part of their carbon supply from other sources, e.g. from autotrophic picoplankton, nanoflagellates, or through functional mixotrophy, since it was estimated that they satisfied only a small fraction of their carbon needs through grazing on bacteria and heterotrophic nanoflagellates (KuuppoLeinikki et al. 1994).

The addition of sticklebacks maintained relatively low metazoan biomass in Units 3 and 4 during the first part of the experiment (Days 1 to 11). The fraction of heterotrophic biomass (including all the other groups except bacteria) of total POC was significantly lower in Units 3 and 4 in comparison to Units 1 and 2 (1-way ANOVA, $\mathrm{p}<0.001$; Tukey's a posteriori test, $\mathrm{p}=0.05$; Days 1 to 11 j. There was also some evidence that the fish addition caused recession of zooplankton grazing on algae in unit 4 and resulted in more rapid development of phytoplankton bloom in Unit 4 than in Unit 2 (Fig 1A), which had no fish during the first half of the experiment, in accordance with the observations concerning the cascading effects of top-down control of algal biomass in lakes (Carpenter et al. 1985, Mazumder et al. 1988)
The qualitative differences of the pelagic food web structure between the 4 manipulated units became more evident during the latter part of the experiment (Days 12 to 21). In all units the biomass fraction of heterotrophic organisms had increased (Fig 3). Although the heterotrophic fraction of total POC was the similar in all units (1-way ANOVA, $\mathrm{p}>0.1$ ), the major groups were quite different. In Units 1 and 4 mesozooplankton dominated the total heterotrophic biomass, while in Units 2 and 3 mainly the protozoan fraction increased (Fig. 3). In Unit 1 copepods were the dominating group, while in Unit 4 the small rotatorian Synchaeta sp. formed most of the total metazoan biomass. In Units 2 and 3 the protozoan biomass increase was mainly due to ciliates, but also amoebaflagellates (i.e. Quadricilia rotundata, which was probably feeding on nanoalgae and diatoms; Vors 1992) and other bacteriovorous flagellates (i.e. Paraphysomonas spp.) were abundant. These qualitative differences indicated that the nutrient enrichments, the cascading effects of top-down manipulations, and the timing of the rotating treatments had a crucial impact on the structural development of the planktonic communities as a whole. The manipulations resulted in diversified functional responses both in the autotrophic and heterotrophic pool of the pelagic ecosystem, which further influenced recycling and flux of inorganic nutrients in the mesocosms.

\section{Nutrient dynamics in the manipulated enclosures}

The most notable difference between the nitrogen and phosphorus dynamics was that in all enclosures phosphorus was retained more effectively within the pelagic system than nitrogen. While the biomass in the manipulated enclosures was increasing, C:N, C:P, and $N$ : $P$ ratios of particulate matter showed generally decreasing trends, the decline of $C: P$ ratio being most pronounced (Table 2). Moreover, the cumulative phosphorus additions were generally detectable in the sum of measured phosphorus fractions, while the measured nitrogen fractions did not always balance the cumulative nitrogen additions (Fig. 4). PP continued to increase and total dissolved phosphorus (DOP $+\mathrm{PO}_{4}-\mathrm{P}$ ) decrease during the periods without any nutrient addition, which indicated rapid mineralization of organic phosphorus as well as effective uptake of phosphate that had accumulated inside the enclosures. Accumulation of DOP in Unit 2 during the third and fourth manipulation period indicated that both bacteria and phytoplankton were incapable of assimilating all available phosphorus either because their biomass growth was controlled by increasing protozoa (Fig 3) or that they were limited by nitrogen for by some other growth-limiting factor). 
The differences between $C: P$ and $N: P$ ratios of settled and suspended particulate material indicated that settled material was phosphorus-impoverished in relation to nitrogen and carbon. Phosphorus is released faster from settling organic material and mineralized more rapidly than nitrogen in aquatic environments (Antia et al. 1963, Garber 1984, Tezuka 1989). Released DOP is generally hydrolyzed rapidly by bacteria, which liberate significant amounts of orthophosphate to surrounding media (Ammermann \& Azam 1985, Tamminen 1989). The insignificant difference between the C:N ratios of settled and suspended material (Table 3) denoted further that nitrogen was lost by sedimentation from the pelagic system to a greater extent than phosphorus in all units.

The N:P ratios of suspended particulate matter decreased only moderately and there were no significant differences due to enrichments. A relatively stable N:P ratio is typical for phytoplankton growing under $N$ limitation, while the $C: N$ ratio varies as a function of phytoplankton growth rates (i.e. nutrient deficiency) (Goldman et al. 1979). Nitrogen has been found to be most often the limiting nutrient for phytoplankton growth during the productive season in the coastal northern Baltic (Tamminen et al. 1985, Kivi et al. 1993). During the present experiment there was apparently the greatest shortage of nitrogen, which is supported by immediate total exhaustion of added ammonium, while there was always a surplus of phosphate in the mesocosms. Moreover, the general range of C:P ratios in manipulated units (50 to 28 by weight) did not indicate $\mathrm{P}$ limitation of the planktonic community (Goldman et al. 1979, Sakshaug \& Olsen 1986).

\section{Impact of the planktonic food web on the retention and loss of nutrients}

In Units 1 and 3 the $C: N$ ratio followed the fraction of autotrophic biomass of total POC (Pearson's correlation coefficient, $r>0.6, p<0.05$ ), which indicated that the phytoplankton biomass development was mainly limited by nitrogen (Davies \& Sleep 1989). Thus, the uptake and loss of nitrogen followed the development of the autotrophic biomass in Units 1 and 3. Moreover, the sedimentary loss of nitrogen was more pronounced than in Units 2 and 4. This infers that in Units 1 and 3 a 'new production' type of system occurred. The rapid bloom development and the following steep biomass decline suggests that the planktonic system was more transitory and had a more temporary character than in Units 2 and 4 . In Units 2 and 4 nitrogen contents of particulate matter did not have any significant relationship with the $\mathrm{C}$ : chl a ratio, indicating that the heterotrophic and/or detrital pool of the pelagic system controlled the retention and loss of nitrogen $(r<0.35$, $p>0.05$ ). This suggested that in Units 2 and 4 the biotic interactions were more coupled and that the pelagic system had shifted to be more 'regenerating' with greater retention capacity for added nutrients and smaller sedimentary losses than in Units 1 and 3

During the second part of the experiment (i.e. Days 12 to 21 ), the highest mean heterotrophic biomass (ca $20 \%$ of the total POC) was in Unit 2 (although it was not significantly different from the other units). In this unit the protozoan biomass increased strongly during the latter part of the experiment (Fig. 3) This suggested that the biomass increase of autotrophic and heterotrophic nanoflagellates ca 5 to $6 \mathrm{~d}$ earlier was efficiently grazed by ciliates and other protozoan micro-organisms (Kuuppo-Leinikki et al. 1994). It seemed likely that in Unit 2 heterotrophic microorganisms could assimilate a considerable fraction of the produced biomass, thus controlling autotrophic production by grazing and retaining more nutrients in the pelagic system. However, there was no indication that the change-over of the fish manipulation on Day 11 into Unit 2 had any effect on mesozooplankton biomass and hence on their predation on ciliates.

The considerable increase of mesozooplankton biomass in Unit 4 (Fig. 3) was unlikely to be due to cessation of fish predation following the change-over of fish manipulation on Day 11. Mesozooplankton biomass was dominated by a small rotifer Synchaeta sp. which formed a clear predator-prey cycle with nanoflagellates and bacteria in Unit 4 (Kuuppo-Leinikki et al. 1994). Rotatorians seem to feed selectively on a wide variety of algae (Egloff 1988) and on bacteria (Sanders et al. 1989). A significant fish-phosphorus enrichment interaction was found to have an effect on rotifer biomass in a freshwater enclosure experiment by Drenner et al. (1989), who postulated that this may have been due to fish suppression on cladocerans and thus reduced competition between cladocerans and rotifers. While there was no increase of other mesozooplankton (i.e. crustaceans; data not shown) after termination of the fish manipulation in Unit 4, this suggested that the carry-over effect of fish predation continued after removal of fish. Thus the coupled fluctuations of bacteria, nanoplankton, and rotifers were probably enhanced due to reduced resource competition between rotifers and crustaceans initjated already during the first part of the experiment.

The development of biomass in Unit 4 differed from the other manipulated units in other respects as well. The fraction of detrital organic material was significantly higher in Unit 4 (ca 48 to $67 \%$ of total POC) than in the other units during the latter part of the experiment (Days 12 to 21 ; 1 -way ANOVA, $p<0.001$; Tukey's a posteriori test, $\mathrm{p}=0.05$ ) which suggested that a large 
fraction of the produced biomass had accumulated in the detrital pool in this unit. Results of the stepwise multiple regression (Table 4) showed that the changes of suspended particulate $\mathrm{C}: \mathrm{N}$ ratio in Units 1 and 3 were mainly controlled by the contribution of the total autotrophic biomass to total POC, while in Unit 4 bacterial biomass resulted in the best correlation with the $C: N$ ratio. In Unit 2 there was no significant correlation. The stepwise regression analysis supported the conclusion that in Units 1 and 3 the $C: N$ ratio was mainly controlled by the development of autotrophic biomass being less affected by the heterotrophic pool of the pelagic system, while in Units 2 and 4 autotrophs did not have a significant influence on the $\mathrm{C}: \mathrm{N}$ ratios of suspended material.

Changes of the C:P ratio in Units 1, 2, and 3 were best explained by models including autotrophic biomass, while also heterotrophs had a significant role for incorporation of $\mathrm{P}$ (Table 4). The insignificant correlations between $\mathrm{C}$ : $\mathrm{Chl} \mathrm{a}$ and $\mathrm{C}: \mathrm{P}$ ratios of particulate matter (Pearson's correlation coefficient, $r=-0.01$ ) and the exclusion of other groups than heterotrophs from the stepwise multiple regression model (Table 4) indicated that phosphorus accumulation (i.e. decrease of $C: P$ ratio) was independent on fluctuations of autotrophic biomass in Unit 4. These results exemplify the important role of pelagic heterotrophs for the retention of phosphorus. Predator-prey cycles within the planktonic food web were apparently crucial for the accumulation of $P$ into the pelagic system during the latter part of the experiment. This may not have been only due to incorporation of $\mathrm{P}$ into their body tissue, but processes like sloppy feeding, fractionation, and rup- turing of algal biomass into dissolved organic form as well as into smaller particulate fractions (Lampert 1978), and coprophagy and related processes (Noji 1991) may have enhanced retention of $P$ in the smallsized detrital particulates. Moreover, the carry-over effects were probably important in phosphorus retention, since no increment of crustacean biomass was observed after the change-over of the fish manipulation. Thus, it seems likely that the recovery of the higher trophic levels after change of fish manipulation did not occur during the second half of the experiment (Days 12 to 21) in Units 3 and 4 . Thus, the development of the planktonic community and the retention of nutrients seemed to continue along the course determined during the first $10 \mathrm{~d}$ of the experiment. Accordingly, the second part of the experiment was not long enough to produce any apparent effects due to the fish manipulation in Units 1 and 2.

\section{Contribution of planktonic biomass fractions to particulate nutrients in the manipulated enclosures}

The elemental ratios of suspended material reflected the average composition of the whole pelagic community including detrital material. Although the actual nutrient ratios of different groups could have been variable, elevated $\mathrm{C}: \mathrm{N}$ ratios occurred when algal biomass declined (especially in Units 1 and 3 where distinct bloom peaks developed) indicating that nitrogen may have been limiting algal growth after culmination of the blooms. However, since the detritus fraction increased concurrently with the decline of algal bio-

Table 4. Stepwise multiple regression analysis of the combined effects of the food web components on the variation of $\mathrm{C}: \mathrm{N}$ and $C: P$ ratios of particulate material in the manipulated units. Independent variables tested were the fractions of autotrophic (Aut \% POC), bacterial (Bac\%POC), other heterotrophs including heterotrophic nanoflagellates, protozoan, and mesozooplankton bromass (Het \% POC), and detrital fraction of total POC (as \%). The minimum criterion for inclusion of the independent variables into the model was $\alpha=0.05$ and 0.10 to remove them (coeff: coefficient of slope; SE: standard error; $t$ : Student's $t$ score; p: probability; $\mathrm{r}^{2}$ coefficient of determination; const.: $y$-intercept; $F$ : F-ratio from ANOVA; n: number of observations; ns: no significant regression)

\begin{tabular}{|c|c|c|c|c|c|c|c|c|c|}
\hline Unit & Independent variable & Coeff. & SE & $t$ & $\mathrm{p}$ & $r^{2}$ & Const. & $F$ & $\mathrm{n}$ \\
\hline \multicolumn{10}{|c|}{ Dependent variable $=\mathrm{C}: \mathrm{N}$ ratio } \\
\hline 1 & Aut $\%$ POC & -0.11 & 0.04 & -3.04 & 0.007 & 0.35 & 10.11 & 9.23 & 19 \\
\hline 2 & ns & & & & & & & & \\
\hline 3 & Aut $\%$ POC & -0.16 & 0.03 & -5.33 & $<0.001$ & 0.60 & 10.55 & 28.4 & 21 \\
\hline 4 & $\mathrm{Bac} \% \mathrm{POC}$ & -0.12 & 0.03 & -3.51 & $<0.003$ & 0.41 & 9.29 & 12.3 & 21 \\
\hline \multicolumn{10}{|c|}{ Dependent variable $=\mathrm{C}: \mathrm{P}$ ratio } \\
\hline \multirow[t]{2}{*}{1} & Aut $\%$ POC & -0.70 & 0.18 & -3.84 & 0.001 & 0.69 & 65.9 & 18.9 & 20 \\
\hline & Het $\%$ POC & -0.82 & 0.35 & -2.31 & 0.034 & & & & \\
\hline \multirow[t]{2}{*}{2} & Aut $\% \mathrm{POC}$ & -0.45 & 0.20 & -2.29 & 0.034 & 0.45 & 53.5 & 7.45 & 21 \\
\hline & Het $\%$ POC & -0.56 & 0.21 & -2.68 & 0.015 & & & & \\
\hline \multirow[t]{2}{*}{3} & Aut $\%$ POC & -0.86 & 0.10 & -8.52 & $<0.001$ & 0.78 & 59.1 & 59.1 & 21 \\
\hline & Het $\% \mathrm{POC}$ & -0.47 & 0.13 & -3.56 & $<0.002$ & & & & \\
\hline 4 & Het $\% \mathrm{POC}$ & -0.64 & 0.23 & -2.76 & 0.013 & 0.29 & 43.3 & 7.60 & 21 \\
\hline
\end{tabular}


A.

PON-distribution

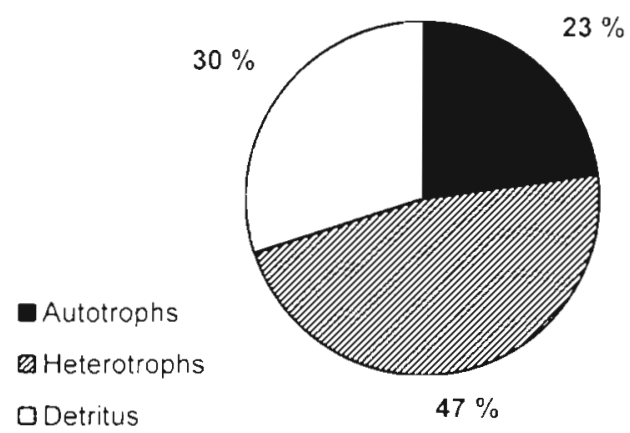

B.

\section{PP-distribution}

\section{Autotrophs}

Heterotrophs 口Detritus

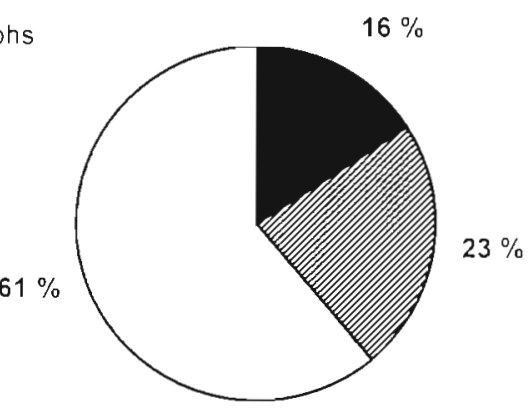

Fig. 5. Average autotrophic, heterotrophic, and detrital biomass (calculated by the difference) fractions of (A) particulate organic nitrogen (PON) and (B) particulate phosphorus (PP) during the experiment. Nitrogen and phosphorus contents of autotrophic and heterotrophic organisms were calculated by using the C:N:P ratios (by werght) from the literature: autotrophs (41:7.2:1, Goldman et al. 1979), bacteria (45:9:1, Goldman et al. 1987), heterotrophic flagellates (C: $N=6.2$, Caron et al. 1990; C:P = 75, Lyche et al. 1996), other protozoa (C:N $=4.7$, Verity 1985; C:P = 44, Lyche et al. 1996), Rotatoria (55:9.7:1, Lyche et al. 1996), Cladocera (50:9.4:1, Andersen \& Hessen 1991), Copepoda ( $\mathrm{C} N=5.3$, Willáms \& Robins 1982; $\mathrm{C}: \mathrm{P}=75$, Andersen \& Hessen 1991)

mass in all units, the phytoplankton $\mathrm{C}: \mathrm{N}$ ratio was more or less masked with this increase. The C:P ratio of algae was probably relatively stable since phosphorus was continuously available for phytoplankton growth and no P limitation occurred. For the calculations, Redfield's C:N:P ratio was used to convert algal carbon biomass to nitrogen and phosphorus units, although the chemical composition of phytoplankton may vary as a function of nutrient availability and growth rate (Goldman et al. 1979, Sakshaug et al. 1983). However, marine phytoplankton growing at high relative growth rates have been shown to have a chemical composition close to Redfield's ratio (Goldman 1986), and for more than half of the time algal biomass in all units was either increasing or stable.
The C:N and C:P ratios of heterotrophic organisms may vary depending on the growth conditions or life cycle stage of the species. For most organisms the elemental composition of their body tissue is relatively stable irrespective of the elemental composition of their food when growing close to the optimal conditions (Williams \& Robins 1982, Goldman et al. 1987 . Caron et al. 1990, Andersen \& Hessen 1991). Total heterotrophic biomass was mostly dominated by bacteria which have low and relatively stable C:N:P ratios regardless of the elemental composition of the substrate. Neither do the variations of gross-growth efficiency have a significant impact on the $\mathrm{C}: \mathrm{N}: \mathrm{P}$ ratio of bacteria (Goldman et al. 1987). Also microprotozod, rotatoria and copepods have relatively low and stable C: $N$ ratios (Williams \& Robins 1982, Verity 1985, Lyche et al. 1996). Based on the nutrient ratios found in the literature, it was estimated that most of the suspended particulate nitrogen was bound to heterotrophic biomass, while most of the suspended particulate phosphorus was found in the detrital fraction (Fig. 5). This indicates that there was a tendency of the pelagic heterotrophs to incorporate $\mathrm{N}$ into their body tissue in excess of $P$ which would have further decreased the $\mathrm{N}: \mathrm{P}$ ratio of remineralized nutrients and strengthened the shortage of inorganic N (Caron et al. 1990, Andersen \& Hessen 1991). While there was always excess of phosphate in the water column, part of the reactive inorganic phosphorus may have adsorbed onto the surfaces of suspended detrital material, thus resulting in a higher concentration of PP in the detrital fraction. On the other hand, the feeding activities of meso- and microzooplankton may have also enhanced rupturing and fractionation of algal and cetrital material into smaller particulates, thus providing more surfaces for $\mathrm{P}$ adsorption or bacterial growth.

\section{Conclusions}

The response of the pelagic system to periodic disturbances (nutrient additions) during summer was fundamentally different from the vernal new production' period. The late summer planktonic community seemed to have a substantial capacity for nutrient retention due to the complexity of the food web. Moreover, timing of the nutrient enrichment in relation to the stability development of the water column (i.e. the initial enclosure of the planktonic community into the mesocosm) was apparently crucial for for the further development of the planktonic community. The cascading effect of the top predator (fish) had a minor impact on the level of pelagic autotrophs and the microbial loop, but fundamentally altered the structure of the heterotrophic community by resulting in diversi- 
fied functional and taxonomic responses of the grazer communities

Efficient removal processes maintained the nitrogen limitation of the pelagic system. All available nitrogen was quickly scavenged from detrital material by the feeding activities of pelagic heterotrophs or by rapid sedimentation of particulate material. The cascading effects of fish predation and predator-prey cycles of planktonic micro-organisms were decisive for the accumulation of phosphorus in the detrital pool of the pelagic system. The results suggest that the feeding activities of the pelagic microheterotrophs enhanced retention and recirculation of phosphorus, while rapid sedimentation and efficient incorporation of nitrogen to the body tissue of heterotrophic micro-organisms resulted in nitrogen deficiency of the pelagic system.

Acknowledgements. We thank R. Autio, S. Hällfors, P. Kuuppo, H. Kuosa, and R. Pajuniemi for providing the planktonic biomass values. We are grateful to P. Alanko, T. Katajisto, and E. Salminen for their assistance in the laboratory and the whole staff of Tvärminne Zoological Station for generous cooperation during the experiment. The Finnish Institute of Marine Research kindly offered their CHN-analyzer for our use. Last, but not least, we acknowledge the whole PELAG research team for conducting the experment with great enthusiasm and endurance, and S. Kaitala for the design of the experimental plan. We also thank P. Kuuppo and $T$ Andersen for critical reading and constructive comments on the manuscript, and the Finnish Environment Institute for providing writıng facilities. This work is a contribution to the project PELAG and was supported by the Academy of Finland (A.-S.H. and T.T.), and by Nordic Collegium for Marine Biology (K.G.).

\section{LITERATURE CITED}

Aksnes DL, Wassmann P (1993) Modeling the significance of zooplankton grazing for export production. Limnol Oceanogr 38:978-985

Ammermann JW, Azam F (1985) Bacterial 5'-nucleotidase in aquatic ecosystems: a novel mechanism of phosphorus regeneration. Science 227:1228-1340

Andersen T, Hessen D (1991) Carbon, nitıogen, and phosphorus content of freshwater zooplankton. Limnol Oceanogr $36: 807-814$

Antra NJ, MCAllister CD, Parsons TR, Stephens K, Strickland JDH (1963) Further measurements of primary production using a large-volume plastic sphere. Limnol Oceanogr 8: $166-183$

Azam F, Fenchel T, Fleld JG, Gray JS, Meyer-Reil LA, Thingstad $F$ (1983) The ecological role of water-column microbes in the sea. Mar Ecol Prog Ser 10:257-263

Bloesch J, Burgi HR (1989) Changes in phytoplankton and zooplankton biomass and composition reflected by sedimentation. Limnol Oceanogr 34:1048-1061

Caron DA. Goldman JC, Dennett MR (1990) Carbon utilization by the omnivorous flagellate Paraphysomonas imperforata. Limnol Oceanogr 35:192-201

Carpenter SR, Kitchell JF, Hodgson JR (1985) Cascading trophic interactions and lake productivity. BioSci 35:634-639

Davies AG. Sleep JA (1989) The photosynthetıc response of nutrient-depleted dilute cultures of Skeletonema costatum to pulses of ammonum and nitrate; the importance of phosphate. J Plankton Res 11:141-164

Drenner RW, Threlkeld ST, Smith JD, Mummert JR, Cantrell PA (1989) Interdependence of phosphorus, fish, and site effects on phytoplankton bıomass and zooplankton. Limnol Oceanogr 34.1315-1321

Egloff DA (1988) Food and growth relations of the marine microzooplankter, Synchaeta cecilia (Rotufera). Hydrobiologia 157:129-141

Elser JJ, Elser MM, Mackay NA, Carpenter SR (1988) Zooplankton mediated transitions between $\mathrm{N}$ - and P-limited algal growth. Limnol Oceanogr 33:1-14

Elser JJ, Foster DK, Hecky RE (1995) Effects of zooplankton on sedimentation in pelagic ecosystems: theory and test in two lakes of the Canadian shield. Biogeochemistry (Dordr) $30: 143-170$

Garber JH (1984) Laboratory study of nitrogen and phosphorus remineralization during decomposition of coastal plankton and seston. Estuar Coast Shelf Sci 18:685-702

Goldman JC (1986) On phytoplankton growth rates and particulate C:N:P ratios at low light. Limnol Oceanogr 31 $1358-1363$

Goldman JC, Caron DA, Dennett MR (1987) Regulation of gross growth efficiency and ammonium regeneration in bacteria by substrate C:N ratio. Limnol Oceanogr 32:1239-1252

Goldman JC: McCarthy JJ, Peavey DG (1979) Growth rate influence on the chemical composition of phytoplankton in oceanic waters. Nature 279:210-215

Granéli E, Olsson P, Carlsson P, Granéli W, Nylander C (1993) Weak 'top-down' control of dinoflagellates growth in the coastal Skagerrak. J Plankton Res 15:213-237

Grasshoff K, Ehrhardt M, Kremling K (1983) Methods of seawater analysıs. Verlag Cheme, Weinheim

Haapala J (1994) Upwelling and ts influence on nutrient concentration in the coastal area of the Hanko peninsula. entrance of the Gulf of Finland. Estuar Coast Shelf Sci 38 $507-521$

Heiskanen AS, Kononen K (1994) Sedimentation of vernal and late summer phytoplankton communties in the coastal Baltic Sea. Arch Hydrobiol 131:175-198

Hessen DO, Nilssen JP, Eriksen TO (1986) Food size spectra and species replacement withın herbivorous zooplankton Int Rev Ges Hydrobiol 71:1-10

Horsted SJ, Nielsen TG, Riemann B, Pock-Steen J, Bjørnsen, PK (1988) Regulation of zooplankton by suspension-feeding buvalves and fish in estuarme enclosures. Mar Ecol Prog Ser 48:217-224

Kivi K (1986) Annual succession of pelagic protozoans and rotifers in the Tvärminne Storfjärden, SW coast of Finland. Ophelia (Suppl) 4:101-110

Kivi K, Kaitala S, Kuosa 11, Kuparınen J, Leskinen E, Lignell R, Marcussen B. Tamminen T (1993) Nutrient limitation and grazing contral of Baltic plankton communty during annual succession. Limnol Oceanogr 38:893-905

Kleppel GS (1993) On the diets of calanoid copepods. Mar Ecol Prog Ser 99:183-195

Kuosa $H$ (1991) Picoplanktonic algae in the northern Baltic Sea: seasonal dynamics and flagellate grazing. Mar Ecol Prog Ser 73:269-276

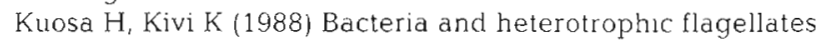
in the pelagic carbon cycle in the northern Baltic Sea. Mar Ecol Prog Ser 53:93-100

Kuuppo-Leinikki P (1990) Protozoan grazing on planktonic bacteria and its impact on bactenal population. Mar Ecol Prog Ser 63:227-238

Kuuppo-Lennikki P, Autio R, Hällfors S, Kuosa H, Kuparinen J. Pajunıemi R (1994) Trophic interactions and carbon flow 
between picoplankton and protozoa in pelagic enclosures manipulated with nutrients and a top predator. Mar Ecol Prog Ser 107:89-102

Lampert W (1978) Release of dissolved orranic carbon by grazing zooplankton. Limnol Oceanogr 23:831--834

Lignell. R (1990) Lxcietion of organic carbon by phytoplankton its relation to algal biomass, primary producivity and bacterial secondary productivity in the Baltic Sea. Nar Ecol Prog Ser 68:85-99

Lignoll R, Lindqvist K (1992) Effect of nutrient enrichment and temperature on intracellular partitioning of ${ }^{14} \mathrm{CO}_{2}$, in a summei phytoplankton community in the northern Baltic. Mar Lcol Prog Ser 86:273-281

Lychn A, Andersen T, Christoffersen K, Hessen DO, Berger Hansen PH, Klysner A (1996) Mesocosm tracer studies: 1. Zooplankton as sources and sinks in the pelagic phosphorus cycle of a mesotrophic lake. Limnol Oceanogr 41: $460-474$

Lynch M, Shapiro J (1981) Predation, enrichment, and phytoplankton community structure. Limnol Oceanogr 26 : 86-102

Mazumder A, MCQueen DJ, Taylor WD, Lean DRS (1988) Effects of fertilization and planktivorous fish (yellow perch) predation on size distribution of particulate phosphorus and assimilated phosphate: large enclosure experiments. Limnol Oceanogr 33:421-430

Mazumder A, Taylor WD, McQueen DJ, Lean DRS (1989) Effects of fertilization and planktivorous fish on epilimnetic phosphorus and phosphorus sedimentation in large enclosures. Can J Fish Aquat Scl 46:1735-1742

Mazumder A, Taylor WD, Lean DRS, MCQueen DJ (1992) Partitioning and fluxes of phosphorus: mechanisms regulating the size-distribution and biomass of plankton. Arch Hydrobiol Beih Ergebn Limnol 35:121-143

McQueen DJ, Post JR, Mills EL (1986) Trophic relations in freshwater pelagic ecosystems. Can J Fish Aquat Sci 43: $1571-1581$

Niemi A (1975) Ecology of phytoplankton in the Tvärminne area, SW coast of Finland. II. Primary production and environmental conditions in the archipelago and the sea zone. Acta Bot Fenn 107:1-73

Noji TT (1991) The influence of macrozooplankton on vertical particulate flux. Sarsia 76:1-9

Peinert R, von Bodungen B. Smetacek $V$ (1989) Food web structure and loss rates. In: Berger $W$, Smetacek $V$, Wefer $G$ (eds) Productivity of the oceans: present and past. John Wiley \& Sons, New York, p 34-48

Riemann B, Nielsen TG. Horsted SJ, Bjørnsen PK, Pock-Steen $J$ (1988) Regulation of phytoplankton biomass in estuarine enclosures. Mar Ecol Prog Ser 48:205-215

Sakshaug E, Andresen K, Myklestad S, Olsen Y (1983) Nutrient status of phytoplankton communities in Norwegian waters (manne, brackish, and iresh) as revealed by their chemical composition. J Plankton Res 5:175-196

Sakshaug E, Olsen Y (1986) Nutrient status of phytoplankton blooms in Norwegian waters and algal strategies for nutnent competition. Can J Fish Aquat Sci 43:398-396

Sanders RW, Porter KG, Bennett SJ, DeBiase AE (1989) Seasonal patterns of bactenovory by flagellates, ciliates, rotifers, and cladocerans in a freshwater plankton community. Limnol Oceanogr 34:673-687

Solorzano L, Sharp JH (1980) Determination of total dissolved phosphorus and particulate phosphorus in natural waters. Limnol Oceanogr 25:754-758

Sommer U (1988) Phytoplankton succussion in microcosm experiments under simultaneous yrazing pressure and resource limitation. Limnol Oceanogr 33:1037-1054

Stcrner RW (1989) The role of grazers in phytoplankton succession. In: Sommer U (ed) Plankton ecology. Brock/ Springer, Berlin, p 107-170

Stoecker DK, Capuzzo JM (1990) Predation on protozoa: its importance to zooplankton. J Plankton Res 12:891-908

Tamminen T (1989) Dissolved organic phosphorus regeneration by bacterioplankton: 5 -nucleotidase activity and subsequent phosphate uptake in a mesocosm enrichment experiment. Mar Ecol Prog Ser 58:89-100

Tamminen T, Kaıtala S, Kivi K, Kuparinen J (1985) Response of planktonic brackish water community to single and combined additions of ammonium and phosphate in a factorial mesocosm experiment. In: Gray J, Christiansen ME (eds) Marine biology in polar regions and effects of stress on marine organisms. John Wiley \& Sons, Chichester, p 363-378

Tezuka Y (1989) The C:N:P ratıo of phytoplankton determines the relative amounts of dissolved inorganic nitrogen and phosphorus released during aerobic decomposition. Hydrobiologia 173:55--62

Thingstad TF, Sakshaug E (1990) Control of phytoplankton growth in nutrient recycling ecosystems. Theory and terminology. Mar Ecol Prog Ser 63:261-272

Threlkeld ST (1988) Planktivory and planktivore bromass effects on zooplankton, phytoplankton, and the trophic cascade. Limnol Oceanogr 33:1362-1375

Uitto A (in press) Role of nanoprotists in metazooplankton nutrition in a mesocosm experiment in the coastal northern Baltic. J Plankton Res

Uitto A, Kaitala S, Kuosa H, Pajunem R (1995) Effect of nutrient addition and predation of mysid shrimp (Neomysis integer) on a Baltic plankton communty in a short term enclosure experiment. Aqua Fenn 25:23-31

Verity P (1985) Grazing, respiration, excretion, and growth rates of tintinnids. Limnol Oceanogr 30:1628-1282

Viitasalo M (1992) Mesozooplankton of the Gulf of Finland and northern Baltic proper - a review of the monitoring data. Ophelia 35:147-168

Vars N (1992) Heterotrophic amoebae, flagellates and heliozoa from the Tvarminne area, Gulf of Finland, in 19881990. Ophelia 36:1-109

Wassmann P (1993) Regulation of vertical export of particulate organic matter from the euphotic zone by planktonic heterotrophs in eutrophicated aquatic environments. Mar Pollut Bull $26: 636-643$

Wehr JD. Campbell Le L (1994) Does microbial biomass affect pelagic ecosystem efficiency? An experimental study Microb Ecol 27:1-17

Williams R, Robms DB (1982) Effects of preservation on wet weight, dry weight, nitrogen, and carbon contents of Calanus helgolandicus (Crustacea: Copepoda). Mar Biol $71: 271-281$

Munuscript first recoived: June 24, 1996

Revised version accepted: October 17, 1996

This article was submitted to the editor 